\title{
Virgibacillus: a new genus to accommodate Bacillus pantothenticus (Proom and Knight 1950). Emended description of Virgibacillus pantothenticus
}

\author{
M. Heyndrickx, ${ }^{1}$ L. Lebbe, ${ }^{1}$ K. Kersters, ${ }^{1}$ P. De Vos, ${ }^{1}$ G. Forsyth ${ }^{2}$ \\ and N. A. Logan ${ }^{2}$
}

Author for correspondence: P. De Vos. Tel: +32 9264 5110. Fax: +3292645346.

e-mail: Paul.Devos@rug.ac.be

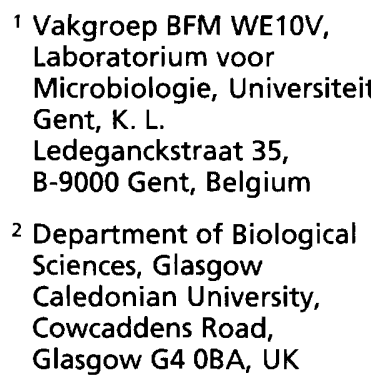

Twelve strains named Bacillus pantothenticus, at least 29 Bacillus strains representing 16 species belonging to rRNA groups 1 and 2, one Bacillus dipsosauri strain, and 38 strains of Amphibacillus, Aneurinibacillus, Brevibacillus, Halobacillus, Paenibacillus, Sporosarcina and Marinococcus, were characterized genotypically using amplified rDNA restriction analysis (ARDRA), and phenotypically using routine diagnostic characters comprising 61 biochemical tests in the API System and 15 observations of vegetative cell and sporangial morphology. The B. pantothenticus strains were also characterized by fatty acid methyl ester analysis and SDS-PAGE of whole-cell proteins. ARDRA revealed that strains of $B$. pantothenticus formed a cluster quite separate from other species in rRNA group 1, supporting the recognition of the former as a separate genus, for which the name Virgibacillus is proposed. The polyphasic data also indicate the presence of an as yet undescribed new species within this genus. The species Virgibacillus pantothenticus and related organisms comprising this new genus can be distinguished from members of Bacillus rRNA group 1 (Bacillus sensu stricto), and from members of Paenibacillus and other aerobic endospore-forming bacteria by routine phenotypic tests.

Keywords: amplified rDNA restriction analysis, Virgibacillus pantothenticus comb. nov., Bacillus, API, fatty acid methyl ester

\section{INTRODUCTION}

Bacillus pantothenticus was described by Proom \& Knight (21) following a nutritional analysis of over 300 mesophilic soil isolates of Bacillus species. Eleven strains requiring pantothenic acid were isolated from eleven different soil samples, taken from widely separated localities in Southern England, by incubating soil suspensions in $4 \% \mathrm{NaCl}$ broth and plating on nutrient agar at $37^{\circ} \mathrm{C}$. They considered them as members of a species most closely resembling Bacillus circulans, but distinct from it, and subsequent studies have confirmed the validity of the species $(3,9,17)$. Later isolations have been made from antacids (3), food, water, bile and soil.

Abbreviations: ARDRA, amplified rDNA restriction analysis; FAME, fatty acid methyl ester; UPGMA, unweighted pair group method using arithmetic averages.
Comparisons of the 16S rRNA sequences of type strains of various Bacillus and Sporosarcina species have indicated that $B$. pantothenticus lies at the periphery of rRNA group 1 of Ash et al. (1) and shows evolutionary relationships with Bacillus smithii and Bacillus badius, the recently described Bacillus dipsosauri and the non-spore-former Marinococcus albus (16), and with the species of the described genus Halobacillus (24), which includes Halobacillus halophilus, formerly classified as Sporosarcina halophila (7).

As a continuation of the collaborative taxonomic study by some members of the International Committee on Systematic Bacteriology Subcommittee on the Taxonomy of the Genus Bacillus (15), representative strains of $B$. pantothenticus and 22 species from Bacillus rRNA group 1 (Bacillus sensu stricto), Bacillus rRNA group 2 and of the related genera 
Table 1. Strains used and the methods used for their characterization

\begin{tabular}{|c|c|c|c|c|c|c|c|}
\hline \multirow[t]{2}{*}{ Name* $^{*}$} & \multirow[t]{2}{*}{ LMG no. } & \multirow[t]{2}{*}{ Other designations $\dagger$} & \multirow[t]{2}{*}{ Source/comment ${ }^{\dagger}$} & \multicolumn{4}{|c|}{ Method applied $\ddagger$} \\
\hline & & & & ARDRA & API & PAGE & FAME \\
\hline A. aneurinilyticus & $15531^{\mathrm{T}}$ & B $0205^{\mathrm{T}}$, NRRL NRS $1589^{\mathrm{T}}$, ATCC $12856^{\mathrm{T}}$ & Gordon & + & + & & \\
\hline A. aneurinilyticus & 15533 & B0207, NRRL NRS 1449, Li strain & Gordon & + & + & & \\
\hline Am. xylanus & $17667^{\mathrm{T}}$ & DSM $6626^{T}$ & DSM & + & + & & \\
\hline B. amyloliquefaciens & $9814^{\mathrm{T}}$ & B0177 , Campbell F, ATCC $23350^{\mathrm{T}}$ & Gordon & + & + & & \\
\hline B. amyloliquefaciens & 12234 & B0168, Fukumoto F & Gordon & + & + & & \\
\hline B. azotoformans & $9581^{\top}$ & CCM $2849^{\mathrm{T}}$ & $\mathrm{CCM}$ & + & + & & \\
\hline B. azotoformans & 15444 & Pichinoty Ba3 & Pichinoty & + & + & & \\
\hline B. badius & $7122^{\mathrm{T}}$ & $\mathrm{B} 0180^{\mathrm{T}}, \mathrm{DSM} 23^{\mathrm{T}}$ & DSM & + & + & & \\
\hline B. badius & 12332 & B0201, NRS 1407, Appleman & Gordon & + & + & & \\
\hline B. cereus & $6923^{\mathrm{T}}$ & B0002 $2^{\mathrm{T}}$, DSM $31^{\mathrm{T}}$, ATCC 14579 , Ford 13 & DSM & + & + & & \\
\hline B. cereus & 12334 & B0358, F $4810 / 73$ (strain 88 ) & Vomit, serogroup 1, Melling & + & + & & \\
\hline B. circulans & $13261^{\mathrm{T}}$ & $\mathrm{B} 0004^{\mathrm{T}}, \operatorname{DSM} 11^{\mathrm{T}}$, ATCC $4513^{\mathrm{T}}$ & DSM & + & + & & \\
\hline B. circulans & 12342 & B0196, NCTC 5846, Morris & Potted crab, NCTC & + & + & & \\
\hline B. dipsosauri & $17413^{\mathrm{T}}$ & NCFB $3027^{\mathrm{T}}$ & NCFB & + & + & & \\
\hline B. firmus & $7125^{\mathrm{T}}$ & B0181 ${ }^{\mathrm{T}}$, DSM $12^{\mathrm{T}}$, ATCC $14575^{\mathrm{T}}$ & DSM & + & + & & \\
\hline B. fusiformis & $9816^{\mathrm{T}}$ & B0658 ${ }^{\mathrm{T}}$, ATCC $7055^{\mathrm{T}}$, Wellcome 2209 & Goodfellow & + & + & & \\
\hline B. fusiformis & 17347 & B0660, Wellcome 2615 & Goodfellow & + & + & & \\
\hline B. insolitus & $17757^{\mathrm{T}}$ & $\begin{array}{l}\text { B0540 }, \text { CCM } 2175^{\mathrm{T}}, \text { ATCC } 2399, \text { B } 0432^{\mathrm{T}} \text {, } \\
\text { Stokes W16 B, DSM } 5^{\mathrm{T}}\end{array}$ & Soil, CCM & + & + & & \\
\hline B. insolitus & 17758 & B0433, Ottow 627 & Goodfellow & & + & & \\
\hline B. lentus & $9579^{\mathrm{T}}$ & 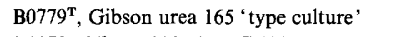 & Gibson & + & + & & \\
\hline B. lentus & 12359 & B0179, Gibson 238, ATCC 10841 & Gibson & + & + & & \\
\hline B. lentus & $16798^{\mathrm{T}}$ & NCIMB $8773^{\mathrm{T}}$ & NCIMB & + & + & & \\
\hline B. licheniformis & 12360 & B0242, Gibson 307 & Gibson & + & + & & \\
\hline B. licheniformis & $12363^{\mathrm{T}}$ & $\mathrm{B} 0245^{\mathrm{T}}, \mathrm{G} 46, \mathrm{NCTC} 10341$ & Gibson & + & + & & \\
\hline B. megaterium & $7127^{\mathrm{T}}$ & $\mathrm{B} 0010^{\mathrm{T}}$, DSM $32^{\mathrm{T}}$, ATCC $14581^{\mathrm{T}}$ & DSM & + & + & & \\
\hline B. megaterium & 12409 & B0621, Hartman NRRL B-348 & Goodfellow & + & + & & \\
\hline B. pantothenticus & $7129^{\mathrm{T}}$ & B0018 ${ }^{\mathrm{T}}$, DSM $26^{\mathrm{T}}$, ATCC $14576^{\mathrm{T}}$ & Soil, DSM & + & + & + & + \\
\hline B. pantothenticus & 12366 & B0183, DSM 490, NCTC 8122 & DSM & + & + & + & + \\
\hline B. pantothenticus & 12367 & B0184, DSM 491, NCTC 8124 & DSM & + & + & + & + \\
\hline B. pantothenticus & 12368 & B0275, NCTC 8123 , Wellcome CN 3020 & Soil, NCTC & + & + & + & + \\
\hline B. pantothenticus & 12369 & B0406, F $2150 / 77$ & Canned chicken, Colindale & + & + & + & + \\
\hline B. pantothenticus & 12370 & B0413, F 2737/77 & Water supply, Colindale & + & + & + & + \\
\hline B. pantothenticus & 17342 & B0802, Wellcome CN 3021 & Soil, Gibson & + & + & + & + \\
\hline B. pantothenticus & 17343 & B0803, Wellcome CN 3022 & Soil, Gibson & + & + & + & + \\
\hline B. pantothenticus & 17344 & B0805, Wellcome CN 3024 & Soil, Gibson & + & + & + & + \\
\hline B. pantothenticus & 17345 & B0806, Wellcome CN 3025 & Soil, Gibson & + & + & + & + \\
\hline B. pantothenticus & 17367 & B0807, Wellcome CN 3026 & Soil, Gibson & + & + & + & + \\
\hline B. pantothenticus & 17369 & B0809, Wellcome CN 3043 & Soil, Gibson & + & + & + & + \\
\hline B. psychrophilus & $6929^{\mathrm{T}}$ & B0434 ${ }^{\mathrm{T}}$, Stokes W16 A, DSM $3^{\mathrm{T}}$ & DSM & + & + & & \\
\hline B. psychrophilus & 17169 & ATCC 23306 & ATCC & + & + & & \\
\hline B. pumilus & $7132^{\mathrm{T}}$ & B0019 $9^{\mathrm{T}}$, DSM $27^{\mathrm{T}}$, ATCC $7061^{\mathrm{T}}$ & DSM & + & + & & \\
\hline B. pumilus & 12259 & B0t02, G 1036, Lister 2812 & Gibson & & + & & \\
\hline B. smithii & 6327 & DSM 459 & DSM & + & + & & \\
\hline B. smithii & $12526^{\mathrm{T}}$ & CCUG $27413^{\mathrm{T}}$ & CCUG & + & + & & \\
\hline B. sphaericus & $7134^{\mathrm{T}}$ & B0012 ${ }^{\mathrm{T}}$, DSM $28^{\mathrm{T}}, \mathrm{G} 1013$ & DSM & + & + & & \\
\hline B. sphaericus & 17382 & B1144, SS II-1 & de Barjac & + & + & & \\
\hline B. subtilis & $7135^{\top 7}$ & B0014 $4^{\mathrm{T}}, \mathrm{DSM} 10^{\mathrm{T}}, \mathrm{ATCC} 6051^{\mathrm{T}}$ & DSM & + & + & & \\
\hline B. subtilis & 17727 & B0905 & Cornish pasty, Sandys & + & + & & \\
\hline$B r . a g r i$ & $15103^{\mathrm{T}}$ & B $4008^{\mathrm{T}}$, CCUG $31345^{\mathrm{T}}$, NRRL NRS $1219^{\mathrm{T}}$ & CCUG & + & + & & \\
\hline Br. agri & 15592 & B4001, NRRL B-1157 & Clinical, Nakamura & + & + & & \\
\hline Br. borstelensis & $16009^{\mathrm{T}}$ & B4029 $9^{\mathrm{T}}$, IFO $15714^{\mathrm{T}}, \mathrm{NRRL}$ NRS $818^{\mathrm{T}}$ & IFO & + & + & & \\
\hline Br. borstelensis & 15599 & B4009, NRRL NRS 1373, 'B. agri' & Hot spring, Nakamura & + & + & & \\
\hline Br. brevis & $16703^{\mathrm{T}}$ & ATCC $8246^{\top}$ & ATCC & + & + & & \\
\hline Br. brevis & 17054 & ATCC 11301, NRS 799 & ATCC & + & + & & \\
\hline Br. formosus & $16010^{\mathrm{T}}$ & $\mathrm{B} 4039^{\mathrm{T}}$, NRRL NRS $863^{\mathrm{T}}$ & Nakamura & + & + & & \\
\hline Br. formosus & 16101 & B4040, NRRL NRS 910 & Nakamura & + & + & & \\
\hline Br. laterosporus & $16000^{\mathrm{T}}$ & B $4035^{\mathrm{T}}$, DSM $25^{\mathrm{T}}$, ATCC $64^{\mathrm{T}}$, Ford 29 & DSM & + & + & & \\
\hline Br. laterosporus & 15436 & B0116, G $1066, ' B$. orpheus' & Gibson & + & + & & \\
\hline Br. parabrevis & $15971^{\mathrm{T}}$ & B $4047^{\mathrm{T}}$, ATCC $10027^{\mathrm{T}}$, NRRL NRS $605^{\mathrm{T}}$ & ATCC & + & + & & \\
\hline Br. parabrevis & 15428 & B027I, G 108, NCTC 7577 & NCTC & + & + & & \\
\hline \multirow[t]{3}{*}{ H. halophilus } & $17431^{\mathrm{T}}$ & DSM $2266^{T}$ & DSM & + & + & & \\
\hline & 17432 & DSM 2500 & DSM & + & + & + & \\
\hline & 17435 & DSM 5938 & DSM & + & + & + & \\
\hline H. trueperi & $17437^{\mathrm{T}}$ & DSM $10404^{T}$ & DSM & + & + & & \\
\hline H. litoralis & $17438^{\mathrm{T}}$ & DSM $10405^{T}$ & DSM & + & + & + & \\
\hline M. albus & $17430^{\mathrm{T}}$ & DSM $20748^{T}$ & DSM & + & + & & \\
\hline M. halophilus & $17439^{\mathrm{T}}$ & DSM $20408^{T}$ & DSM & + & + & & \\
\hline P. alvei & $13253^{\mathrm{T}}$ & B0016 ${ }^{\mathrm{T}}$, DSM $29^{\mathrm{T}}$ & DSM & + & + & & \\
\hline P. alvei & 13254 & B0610, CN 2772 & Goodfellow & + & + & & \\
\hline P. azotofixans & $14658^{\mathrm{T}}$ & B1406 ${ }^{\mathrm{T}}$, Seldin P3L5 & Seldin & + & + & & \\
\hline P. azotofixans & 14659 & B1407, Seldin F-102 & Seldin & + & + & & \\
\hline P. larvae subsp. larvae & $9820^{\mathrm{T}}$ & $\mathrm{B} 1415^{\mathrm{T}}, \mathrm{ATCC} 9545^{\mathrm{T}}$ & ATCC & + & + & & \\
\hline P. larvae subsp. larvae & 14425 & B1416, ATCC 25747 & ATCC & + & + & & \\
\hline
\end{tabular}


Virgibacillus gen. nov.

Table 1 (cont.)

\begin{tabular}{|c|c|c|c|c|c|c|c|}
\hline \multirow[t]{2}{*}{ Name* $^{*}$} & \multirow[t]{2}{*}{ LMG no. } & \multirow[t]{2}{*}{ Other designations $\dagger$} & \multirow[t]{2}{*}{ Source/comment ${ }^{\dagger}$} & \multicolumn{4}{|c|}{ Method applied $\ddagger$} \\
\hline & & & & ARDRA & API & PAGE & FAME \\
\hline P. lautus & $11157^{\mathrm{T}}$ & B1396 $6^{\mathrm{T}}$, DSM $3035^{\mathrm{T}}$, B. Henry 160 & DSM & + & + & & \\
\hline P. lautus & 14015 & B1388, NRRL NRS-1171 & Nakamura & + & + & & \\
\hline P. macerans & $13281^{\mathrm{T}}$ & B $0497^{\mathrm{T}}$, NCTC $6335^{\mathrm{T}}$ & NCTC & + & + & & \\
\hline P. macerans & 13283 & B0110, Gibson 557 & Gibson & + & + & & \\
\hline P. polymyxa & $13294^{\mathrm{T}}$ & B $0011^{\mathrm{T}}$, DSM $36^{\mathrm{T}}$ & DSM & + & + & & \\
\hline P. polymyxa & 13296 & B0264 ${ }^{\mathrm{T}}$, Gibson 43 , NCTC 7575 & Gibson & + & + & & \\
\hline P. validus & $11161^{\mathrm{T}}$ & B $1397^{\mathrm{T}}$, DSM $3037^{\mathrm{T}}$ & DSM & + & + & & \\
\hline P. validus & 14018 & B1392, NRRL NRS-838A & Nakamura & + & + & & \\
\hline S. ureae & $17366^{T}$ & B $0819^{\mathrm{T}}$, G 181 , NRS 42, CCM $684^{\mathrm{T}}$, & $\mathrm{CCM}$ & + & + & & \\
\hline S. ureae & 17363 & B0727, G urea 155 & Gibson & + & + & & \\
\hline
\end{tabular}

* Genus abbreviations: A., Aneurinibacillus; Am., Amphibacillus; B., Bacillus; Br., Brevibacillus; H., Halobacillus; M., Marinococcus; P., Paenibacillus; S., Sporosarcina.

† ATCC, American Type Culture Collection, Rockville, MD, USA; B, N. A. Logan Bacillus collection, Glasgow Caledonian University, Glasgow, UK; CCUG, Culture Collection University of Göteborg, Göteborg, Sweden; CN, Wellcome Collection of Microorganisms, Beckenham, Kent, UK; De Barjac, Institut Pasteur, Paris, France; DSM, Deutsche Sammlung von Mikroorganismen und Zellkulturen, Braunschweig, Germany; Gibson, T. Gibson collection, held at University of Bristol, Bristol, UK; Gordon, Rutgers University, New Brunswick, USA; Goodfellow, University of Newcastle, Newcastle upon Tyne, UK; LMG, BCCM/LMG Bacteria collection Laboratorium voor Microbiologie, Universiteit Gent, Gent, Belgium; Nakamura, US Department of Agriculture, Peoria, IL, USA; NCFB, National Collection of Food Bacteria, AFRC Institute of Food Research, Reading, UK; NCIMB, National Collection of Industrial and Marine Bacteria, Aberdeen, UK; NCTC, National Collection of Type Cultures, Central Public Health Laboratory, London, UK; NRRL, Northern Regional Research Laboratory collection, Peoria, IL, USA; NRS, N. R. Smith collection; Pichinoty, UER Scientifique de Luminy, Marseille, France; Seldin, Universidade Federal do Rio de Janeiro, Rio de Janeiro, Brazil.

†PI, tests in the API system, other biochemical tests and morphological observations; ARDRA, amplified rDNA restriction analysis; FAME, fatty acid methyl ester; PAGE of whole-cell proteins.

Aneurinibacillus, Brevibacillus and Paenibacillus were initially characterized by amplified rDNA restriction analysis (ARDRA) (14). This method revealed that $B$. pantothenticus represents a phylogenetic group sufficiently different from other Bacillus species to warrant the status of a separate genus. We therefore carried out a polyphasic taxonomic study, which also included strains of Amphibacillus xylanus, Halobacillus halophilus, Halobacillus trueperi, Halobacillus litoralis, Marinococcus halophilus and Marinococcus albus, to clarify the positions of these strains at different taxonomic levels. We report here on the findings of that study, which support the recognition of a new genus, which we name Virgibacillus, to accommodate $B$. pantothenticus and related organisms which appear to belong to an as-yet-undescribed new species.

\section{METHODS}

Strains and media. The designations of the strains, their origins and the different methods applied are shown in Table 1. Unless otherwise stated, Bacillus pantothenticus strains were grown on Trypticase Soy agar (TSA) and the other Bacillus strains on nutrient agar with $1 \%(\mathrm{w} / \mathrm{v})$ glucose (NAG) at $30^{\circ} \mathrm{C}$ for $24-48 \mathrm{~h}$. The Halobacillus strains were grown on Bacto Marine agar (Difco) at $30^{\circ} \mathrm{C}$ and Bacillus dipsosauri on TSA supplemented with $1 \mathrm{M} \mathrm{KCl}$ at $37^{\circ} \mathrm{C}$. Marinococcus albus and Marinococcus halophilus were grown on the $M$. albus medium at 37 and $30^{\circ} \mathrm{C}$, respectively (6). Amphibacillus xylanus was grown at $37^{\circ} \mathrm{C}$ aerobically and anaerobically (Anaerobic System, Forma Scientific model 1024) on the medium described by Niimura et al. (18). The strains were checked for purity by plating and phasecontrast microscopy, and were maintained both as lyophilized cultures and (except for Marinococcus strains) as sporulated cultures on slopes of the appropriate abovementioned medium containing $5 \mathrm{mg} \mathrm{MnSO}_{4} .4 \mathrm{H}_{2} \mathrm{O}^{-1}$ (to enhance sporulation). Slopes were incubated for $48 \mathrm{~h}$ or longer, until spores could be observed by microscopy, then stored in the dark at $4{ }^{\circ} \mathrm{C}$.

DNA preparation. Total genomic DNA was purified using a slight modification of the method of Pitcher et al. (19), as described previously (14). DNA was prepared from $A$. xylanus grown aerobically as well as anaerobically. The DNA preparations were visually inspected by $1 \%(\mathrm{w} / \mathrm{v})$ agarose gel electrophoresis, quantified spectrophotometrically at $260 \mathrm{~nm}$, and stored at $-20^{\circ} \mathrm{C}$.

ARDRA. Enzymically amplified 16S rDNA was obtained by PCR and analysed by restriction digestion with five restriction enzymes (HaeIII, DpnII, RsaI, BfaI and Tru9I) as described previously (14). The restriction patterns for each strain were normalized and combined. The combined patterns were subjected to numerical analysis by the Gelcompar 4.0 software (Applied Maths) using the Dice coefficient and the unweighted pair group method using arithmetic averages (UPGMA) clustering algorithm.

GC analysis of fatty acid methyl esters (FAMEs). Cells were grown on TSA at $28^{\circ} \mathrm{C}$ for $24 \mathrm{~h}$ as recommended by the Microbial Identification System (MIS; Microbial ID). Methods for fatty acid extraction, methyl ester preparation and methyl ester separation by GC were described previously 
(25). The FAME profiles were identified and clustered using the MIS software version 4.0.

SDSPAGE of whole-cell proteins. Cells for SDS-PAGE were obtained after a $24 \mathrm{~h}$ growth on nutrient agar with $1 \%(\mathrm{w} / \mathrm{v})$ glucose (NAG) at $30^{\circ} \mathrm{C}$. Methods for preparation and electrophoresis of SDS protein extracts and for UPGMA cluster analysis of the protein profiles were described previously $(20,26)$.

Phenotypic characterization and numerical analysis. Strains were grown on TSA or, in the case of B. dipsosauri, Amphibacillus, Halobacillus and Marinococcus strains, on the special media mentioned above, and were characterized by the methods of Logan \& Berkeley (16), using API tests and microscopic characters: 12 miscellaneous biochemical tests from the API 20E strip and 49 carbohydrate tests in the API $50 \mathrm{CH}$ gallery (using the API CHB suspension medium) were accompanied by 15 observations on vegetative cells and sporangia by phase-contrast microscopy (presence of motile cells, chains of cells, curved rods, rods with tapered ends, vacuoles, spores, swollen sporangia, parasporal crystals, parasporal bodies; shape of spores ellipsoidal, cylindrical or spherical, position of spores terminal, subterminal or central/paracentral). Biochemical tests were scored on a range of 0 (negative) to 5 (strong positive); microscopic observations were scored as 0 (absent/negative) or 1 (present/positive). Redundant tests (i.e. positive or negative for all strains) were excluded, and the data were subjected to numerical taxonomic analysis using the Genstat 5 program. Similarities were calculated using the general similarity coefficient of Gower $\left(S_{\mathrm{G}}\right)(10)$. Where two organisms were both negative for an API test, such a matching was given a weighting of zero in the calculation to avoid negative results making undue contributions to similarity. The results were then examined by UPGMA cluster analysis.

\section{RESULTS AND DISCUSSION}

The 12 B. pantothenticus strains clustered together, but separate from all the other organisms studied, in the numerical analysis of their combined ARDRA patterns, and are subdivided into two groups (Fig. 1). The largest group, forming at a similarity level of $92 \%$, consisted of 10 strains and included the type strain of $B$. pantothenticus, LMG $7129^{\mathrm{T}}$. Nearest neighbours of this group, joining at a similarity level of $81 \%$, were $B$. pantothenticus LMG 12370 and $B$. pantothenticus LMG 17369, which showed an ARDRA similarity of $91 \%$ to each other. This cluster of 12 strains, henceforth referred to as the $B$. pantothenticus group, was as a whole somewhat more closely related (similarity level $58 \%$ ) to the spore-forming halophilic organisms $B$. dipsosauri, H. halophilus, $H$. litoralis and $H$. trueperi, to the halophilic non-spore-forming organism $M$. albus and to the spore-forming alkaliphilic organism $A$. xylanus, than to Bacillus rRNA groups 1 and 2 (1), Paenibacillus (formerly Bacillus rRNA group 3) (2), and Aneurinibacillus and Brevibacillus (formerly $\mathrm{Ba}$ cillus rRNA group 4) (23). This ARDRA clustering of the $B$. pantothenticus group is consistent with the most recent phylogenetic trees based upon 16S rRNA (rDNA) sequences of type strains alone $(16,23,24)$.

It is noteworthy that according to the ARDRA patterns, $M$. halophilus (type species of the genus) belongs to a separate phylogenetic lineage which agrees well with the sequence analysis of Farrow et al. (8). $M$. albus did not show any appreciable relationship by ARDRA to the former species, confirming the sequence analysis of Lawson et al. (16) and suggesting that it should be removed from the genus Marinococcus.

Numerical analysis of SDS-PAGE patterns of whole cell proteins (data not shown) showed a similar arrangement of the $B$. pantothenticus group (except for $B$. pantothenticus LMG 12366) as that seen with ARDRA (Fig. 1): a large group (nine strains), including $B$. pantothenticus LMG $7129^{\mathrm{T}}$, showing identical protein patterns (similarity level of at least $90 \%$ ), and the two strains $B$. pantothenticus LMG 12370 and $B$. pantothenticus LMG 17369 having a mutual similarity of $95 \%$, and linking with the larger group at $80 \%$ similarity. The exception, B. pantothenticus LMG 12366 , was found as the nearest neighbour of the larger group of nine strains at $80 \%$ similarity. The slightly aberrant clustering of this strain with respect to the ARDRA picture was caused by a dense protein band with a molecular mass of $56 \mathrm{kDa}$. Indeed, by exclusion of this band (5) from numerical analysis, this strain joined the group of nine strains containing the $B$. pantothenticus type strain. $H$. halophilus strains LMG 17432,17435 and 17438, which could be cultivated on NAG after a preculture on Bacto Marine agar, showed completely different protein patterns and are thus clearly distinct from the $B$. pantothenticus group.

In a numerical analysis of the FAME data of the $B$. pantothenticus group (not shown), the same $10 \mathrm{~B}$. pantothenticus strains as in the ARDRA analysis (Fig. 1) formed a cluster at a Euclidian distance of $12 \cdot 7 . B$. pantothenticus LMG 12367 was the only strain linked at the lower border of this cluster. All of the nine other strains grouped within a Euclidian distance of about 10 , a level which has recently been suggested for species delineation (22). The mean fatty acid profile (Table 2) of this group probably represents the authentic $B$. pantothenticus species, and consists of major amounts of anteiso- $\mathrm{C}_{15: 0}$, iso- $\mathrm{C}_{15: 0}$, anteiso$\mathrm{C}_{17: 0}$ and iso- $\mathrm{C}_{16: 0}$, with an iso- $\mathrm{C}_{15: 0} /$ anteiso- $\mathrm{C}_{15: 0}$ ratio of 0.33 . B. pantothenticus $\mathrm{LMG} 12370$ and $B$. pantothenticus LMG 17369 , clustering together at a Euclidian distance of 7.0, again have a distinct position, lying at 24.6 Euclidian distance from the main $B$. pantothenticus group. The main difference in their mean fatty acid profile (Table 2, group 2) was a higher iso- $\mathrm{C}_{15: 0}$ /anteiso- $\mathrm{C}_{15: 0}$ ratio of around 1.0.

In the numerical analysis of API tests and other phenotypic characters (data not shown), the B. pantothenticus group was divided into two distinct clusters which merged at $67 \% S_{\mathrm{G}}$ and which then joined with the clusters containing most of the other Bacillus species at $46 \% S_{\mathrm{G}}$. This separation reflects distinct biochemical and morphological profiles for B. pantothenticus which allow its ready separation from other aerobic endospore-forming bacteria and from Marinococcus. The larger of the two B. pantothenticus clusters 


$\begin{array}{llllllll}30 & 40 & 50 & 60 & 70 & 80 & 90 & 100\end{array}$

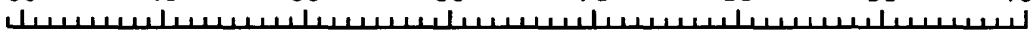

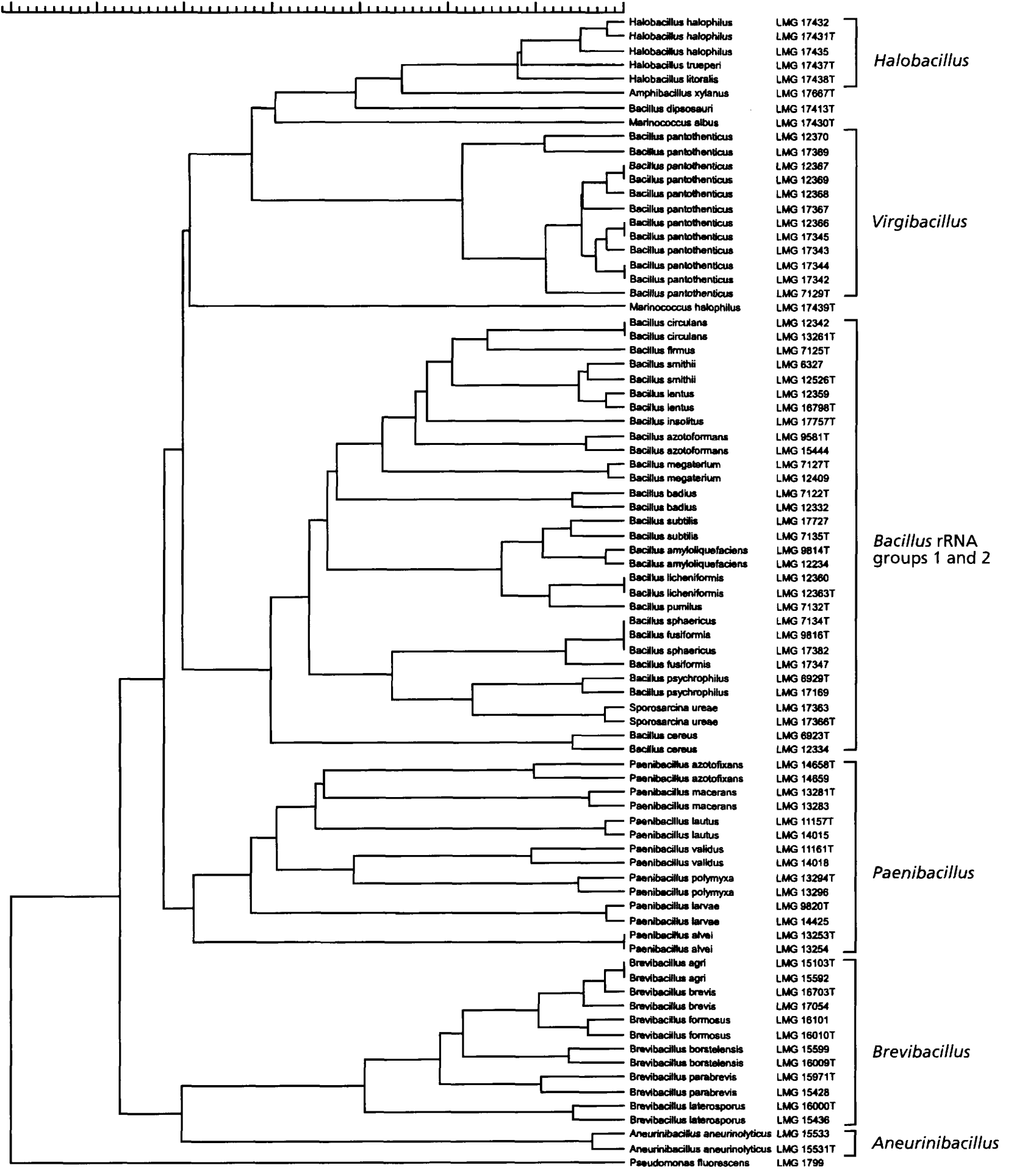

Fig. 1. Dendrogram based on the UPGMA clustering of similarity coefficients $\left(S_{D}\right)$ of normalized combined 165 rDNA restriction profiles (ARDRA) of 12 Bacillus pantothenticus (here reclassified as Virgibacillus pantothenticus) strains, the type strain of $B$. dipsosauri, five Halobacillus strains and two Marinococcus strains. To show the localization of the $V$. pantothenticus strains, we included 29 representatives of Bacillus rRNA groups 1 and 2, 14 Paenibacillus strains, 12 Brevibacillus strains, two strains of Aneurinibacillus and two strains of Sporosarcina ureae. Restriction enzymes used were HaellI, Dpnll, Rsal, Bfal and Tru9I. Pseudomonas fluorescens LMG 1799 was used as outgroup reference. T indicates position of type strain. 
Table 2. Comparison of the mean fatty acid profile of 12 named $B$. pantothenticus strains as measured by GC analysis of their methyl esters

The data given are mean values with the minimal and maximal values within the particular group of strains given below. Only fatty acids accounting for at least $0.5 \%$ of the total fatty acid content are listed.

\begin{tabular}{|c|c|c|c|c|c|c|c|c|c|c|}
\hline Fatty acid... & $\begin{array}{l}\text { 13:0 } \\
\text { Iso }\end{array}$ & $\begin{array}{c}\text { 13:0 } \\
\text { Anteiso }\end{array}$ & $\begin{array}{l}14: 0 \\
\text { Iso }\end{array}$ & $14: 0$ & $\begin{array}{l}15: 0 \\
\text { Iso }\end{array}$ & $\begin{array}{c}\text { 15:0 } \\
\text { Anteiso }\end{array}$ & $\begin{array}{l}16: 0 \\
\text { Iso }\end{array}$ & $16: 0$ & $\begin{array}{l}17: 0 \\
\text { Iso }\end{array}$ & $\begin{array}{c}\text { 17:0 } \\
\text { Anteiso }\end{array}$ \\
\hline \multirow{2}{*}{$\begin{array}{l}\text { B. pantothenticus } \\
\text { group } 1^{*}\end{array}$} & & 0.5 & $4 \cdot 3$ & $1 \cdot 2$ & $15 \cdot 8$ & $47 \cdot 4$ & $8 \cdot 3$ & $5 \cdot 2$ & $2 \cdot 8$ & $13 \cdot 5$ \\
\hline & & $0 \cdot 0-0 \cdot 87$ & $2 \cdot 7-6 \cdot 4$ & $0 \cdot 7-1 \cdot 6$ & $11 \cdot 9-19 \cdot 2$ & $37 \cdot 8-52 \cdot 0$ & $6 \cdot 4-11 \cdot 2$ & $3 \cdot 2-8 \cdot 1$ & $2 \cdot 1-3 \cdot 3$ & $10 \cdot 3-18 \cdot 9$ \\
\hline \multirow{2}{*}{$\begin{array}{l}\text { B. pantothenticus } \\
\text { group } 2 \dagger\end{array}$} & $1 \cdot 4$ & 0.7 & 3.8 & $2 \cdot 0$ & $34 \cdot 9$ & $34 \cdot 0$ & $4 \cdot 1$ & 8.8 & $5 \cdot 1$ & $5 \cdot 7$ \\
\hline & $1 \cdot 1-1 \cdot 6$ & $0-0.7$ & $2 \cdot 9-4 \cdot 6$ & $1 \cdot 6-2 \cdot 4$ & $34 \cdot 8-35 \cdot 1$ & $31 \cdot 9-36 \cdot 1$ & $3 \cdot 9-4 \cdot 2$ & $6 \cdot 7-10 \cdot 9$ & $4 \cdot 0-6 \cdot 2$ & $4 \cdot 9-6 \cdot 4$ \\
\hline
\end{tabular}

* Group 1 consists of strains LMG 7129 $, 17342,17367,17344,12366,17345,12368,17343,12369$ and 12367.

$\dagger$ Group 2 consists of strains LMG 12370 and 17369.

formed at $76 \% S_{\mathrm{G}}$, and contained the same 10 strains that clustered together in the ARDRA (Fig. 1), PAGE and FAME dendrograms. The two remaining strains of $B$. pantothenticus (LMG 12370 and 17369) clustered loosely at $70 \% S_{\mathrm{G}}$, a result also consistent with the findings of the ARDRA (Fig. 1), SDS-PAGE and FAME analyses. Given that, in ARDRA, $M$. albus LMG 17430 clustered with Halobacillus strains, and yet $M$. halophilus showed no appreciable relatedness to $M$. albus, it is of interest that the strains of Halobacillus and $M$. albus also clustered together in the API and other phenotypic test analysis, while $M$. halophilus was recovered as an outlier of the Bacillus subtilis, Bacillus licheniformis and Bacillus pumilus cluster, joining at $55 \% S_{\mathrm{G}}$, finally joining with the Halobacillus and $M$. albus cluster at only $29.5 \% S_{\mathrm{G}}$.

In conclusion, our polyphasic data show that the $B$. pantothenticus group is distinct from Bacillus rRNA groups 1 and 2 , as well as from the related genera Paenibacillus, Brevibacillus and Aneurinibacillus. Although it shows a distant phylogenetic relationship to the alkaliphilic spore-forming genus Amphibacillus, to the moderately halophilic spore-forming genus Halobacillus, and to the moderately halophilic non-sporeforming genus Marinococcus, it differs from the last two genera in its facultative anaerobic metabolism and from each of the three mentioned genera in the following respective characteristics (Table 3): Amphibacillus is an obligate alkalophile and lacks isoprenoid quinones (18), Halobacillus contains an uncommon cell wall murein of the Orn-D-Asp type (24), whereas $B$. pantothenticus contains a cell wall murein based on meso-diaminopimelic acid like most Bacillus spp. (3), and Marinococcus differs by its inability to grow on media without $\mathrm{NaCl}$, its coccoid morphology and its absence of endospores (11). Therefore we propose to elevate the $B$. pantothenticus group to the rank of genus, for which we propose the name Virgibacillus gen. nov. At present this genus contains only one validly described species, the type species $V$. pantothenticus. However our polyphasic data indicate that strains LMG 12370 and 17369 represent a new Virgibacillus species; more strains must be obtained and characterized to describe the phenotypic and genotypic variation of this species.

The description of the new genus and an emended description of its species follow, and a comparison of some of the salient features of other genera of aerobic spore-forming bacteria and Marinococcus, is shown in Table 3. Cultural, microscopic and API characters, and the fatty acid profile were obtained in the present study. Other characters are taken from the description of $B$. pantothenticus given by Claus \& Berkeley (3).

\section{Description of Virgibacillus gen. nov.}

Virgibacillus (Vir.gi.ba.cil'lus. L. n. virga a green twig, transf., a branch in a family tree; L. dim. n. bacillus from Bacillus, a genus of aerobic endospore-forming bacteria; Virgibacillus a branch of the genus Bacillus).

Cells are motile, Gram-positive rods $(0.5-0.7$ by $2-5 \mu \mathrm{m})$ which often form chains. They bear spherical to ellipsoidal endospores which lie in terminal, sometimes subterminal, positions in swollen sporangia. After $2 \mathrm{~d}$ on Trypticase Soy agar colonies are small $(0.5-2 \mathrm{~mm}$ in diameter $)$, circular and slightly irregular, smooth, glossy or sometimes matt, flat, butyrous, creamy to yellowish white and almost opaque. Members of the genus are facultatively anaerobic and catalase positive. They have a nutritional requirement for pantothenic acid, thiamin, biotin and amino acids. In the API 20E strip and in conventional tests the Voges-Proskauer reaction is negative, indole is not produced, nitrate reduction to nitrite is variable. Hydrolysis of casein and of aesculin positive, hydrolysis of gelatin usually positive, and hydrogen sulphide is usually not produced (but a few strains give weak positive reactions in the API $20 \mathrm{E}$ strip). A few strains also give positive reactions for arginine dihydrolase, citrate utilization and ONPG in the API $20 \mathrm{E}$ strip. Growth is stimulated by $4 \% \mathrm{NaCl}$ and not inhibited by $10 \% \mathrm{NaCl}$. Growth may occur between 
Table 3. Salient features of some genera of aerobic, endospore-forming bacteria and Marinococcus

Characters are taken from the following references: Bacillus (3), Paenibacillus (13), Aneurinibacillus (12, 23), Brevibacillus (23), Halobacillus (24), Alicyclobacillus (28), Amphibacillus (18), Sporosarcina (4), and Marinococcus (11). Abbreviations: DAP, directlinked meso-diaminopimelic acid; E, ellipsoidal; S, spherical; E-S, ellipsoidal to spherical; C, cyclindrical; B, ellipsoidal or cylindrical spores bent into kidney or banana shape; $\mathrm{V}$, character varies according to species.

\begin{tabular}{|c|c|c|c|c|c|c|c|c|c|c|}
\hline Character & Virgibacillus & Bacillus & Paenibacillus & Aneurinibacillus & Brevibacillus & Halobacillus & Alicyclobacillus & Amphibacillus & Sporosarcina & Marinococcus \\
\hline No. of species & 1 & $>60$ & 13 & 2 & 10 & 3 & 3 & 1 & 1 & 3 \\
\hline Murein & DAP & $\mathrm{V}^{*}$ & DAP & DAP & DAP & Orn-D-Asp & $\mathrm{ND}$ & DAP & L-Lys-Gly-D-Glu & DAP \\
\hline Cell shape & Rods & Rods & Rods & Rods & Rods & Rods and cocci & Rods & Rods & Cocci & Cocci \\
\hline Spores & + & + & + & + & + & + & + & + & + & - \\
\hline Spore shape & $\mathrm{E}-\mathrm{S}$ & $\mathrm{E}, \mathrm{C}, \mathrm{S}, \mathrm{B}$ & $\mathrm{E}$ & $\mathbf{E}$ & $\mathrm{E}$ & E, $S$ & E & $\mathrm{E}$ & $\mathrm{S}$ & $\mathrm{NA}$ \\
\hline Sporangia swollen & + & V & + & + & + & $+/ \mathrm{NA}$ & $+1-$ & ND & $\mathrm{NA}$ & $\mathrm{NA}$ \\
\hline Anaerobic growth & + & V & $\mathrm{V}$ & - & $+1-$ & - & V & + & - & - \\
\hline $\begin{array}{l}\text { Optimum } \\
\text { temperature }\left({ }^{\circ} \mathrm{C}\right)\end{array}$ & 37 & $15-55$ & 30 & 37 & $30-48$ & 35 & $48-65$ & 37 & 30 & 30 \\
\hline Optimum pH & 7 & $7-9 \cdot 5$ & 7 & 7 & 7 & $7 \cdot 5$ & 3 & $9-10$ & 8 & 7.5 \\
\hline $\begin{array}{l}\text { Growth in } \\
10 \% \mathrm{NaCl}\end{array}$ & + & V & - & - & - & + & - & - & - & + \\
\hline $\begin{array}{l}\text { Major isoprenoid } \\
\text { quinone }\end{array}$ & MK-7 & MK-7 & MK-7 & MK-7 & MK-7 & MK-7 & MK-7 & None & MK-7 & MK-7 (MK-8) \\
\hline $\begin{array}{l}\text { Major cellular } \\
\text { fatty acids }\end{array}$ & Iso + anteiso- $\mathrm{C}_{15: 0}$ & $\mathrm{~V}$ & Anteiso- $\mathrm{C}_{15: 0}$ & $\begin{array}{l}\text { iso- } \mathrm{C}_{15: 0}, \mathrm{C}_{16: 0} \\
\quad \text { iso- } \mathrm{C}_{16: 0}\end{array}$ & $\begin{array}{l}\text { Anteiso- } \mathrm{C}_{15: 0} \\
\quad+\text { iso- } \mathrm{C}_{15: 0} \\
\text { or just iso- } \mathrm{C}_{15: 0}\end{array}$ & ND & $\omega$-Alicyctic acids & $\begin{array}{l}\text { Anteiso- } C_{15: 0} \\
C_{16: 0}, \text { iso- } C_{16: 0}\end{array}$ & $\mathrm{ND}$ & ND \\
\hline $\mathrm{G}+\mathrm{C}\left(T_{\mathrm{m}}\right)$ & $36 \cdot 9 \dagger-38 \cdot 3 \ddagger$ & $32-69$ & $40-54$ & $41 \cdot 1-43 \cdot 4$ & $42 \cdot 8-57 \cdot 4$ & $40-43$ & $51 \cdot 6-60 \cdot 3$ & $36-38$ & $40-41 \cdot 5$ & $44 \cdot 9-49 \cdot 3$ \\
\hline
\end{tabular}

NA, Not applicable.

ND, No data available.

* Predominant type is DAP.

$\dagger$ According to Fahmy et al. (7).

$\ddagger$ Mean of two measurments ( $T_{\mathrm{m}}$ method).

15 and $50^{\circ} \mathrm{C}$, with an optimum of about $37^{\circ} \mathrm{C}$. Acid without gas is produced from the following carbohydrates in the API 50CHB gallery: $N$-acetylglucosamine, arbutin, D-fructose, galactose, D-glucose, maltose, D-mannose, ribose, salicin, D-tagatose, trehalose; acid production from the following carbohydrates is variable: amygdalin, D-arabinose, cellobiose, L-fucose, $\beta$-gentiobiose, gluconate, glycerol, glycogen, inositol, lactose, methyl $\alpha$-D-glucoside, methyl $\alpha$-D-mannoside, rhamnose, sorbitol, starch, sucrose and D-turanose. The major cellular fatty acids are iso- $\mathrm{C}_{15: 0}$ and anteiso- $\mathrm{C}_{15: 0}$. The major quinone is menaquinone 7 (27). Murein of the type strain of the type species has been reported as meso-DAP direct type (3). The $\mathrm{G}+\mathrm{C}$ content has been reported (7) as $36.9\left(T_{\mathrm{m}}\right)$ while we found $38.3 \mathrm{~mol} \%$ to be the mean of two determinations for the type strain of the only species, Virgibacillus pantothenticus.

\section{Description of Virgibacillus pantothenticus (Proom and Knight 1950, 539 ${ }^{\text {AL }}$ ) comb. nov.}

The description is identical to that given by Claus \& Berkeley (3) and to the description of the genus given above. The type strain is strain ATCC $14576(=\mathrm{LMG}$ 7129 , NCIMB 8775, NCTC 8162). In the variable API characters listed above, its reactions are positive for $\mathrm{H}_{2} \mathrm{~S}$ production (weak), citrate utilization, gelatin hydrolysis, and production of acid without gas from: amygdalin, methyl $\alpha$-D-glucoside, methyl $\alpha$-D-mannoside, rhamnose, starch, sucrose and D-turanose; its reactions are negative for arginine dihydrolase, nitrate reduction, ONPG, and for production of acid without gas from $\mathrm{D}$-arabinose, cellobiose, L-fucose, $\beta$-gentiobiose, gluconate, glycerol, glycogen, inositol, lactose and sorbitol.

\section{ACKNOWLEDGEMENTS}

We are most grateful to bioMérieux for providing API materials and for supporting G.F.; P.D.V. and M.H. are indebted to the Fund for Scientific Research (Belgium) for a position as Senior Research Associate and Postdoctoral Research Fellow, respectively. M.H., N.A.L. and P.D.V. are most grateful to the British Council and the Fund for Scientific Research (Belgium) for a travel grant from the Academic Research Collaboration Programme. P.D.V. thanks the 'Onderzoeksfonds RUG' for personnel and research grants nos 01105893 and 011A1096. K. K. acknowledges the Fund for Medical Scientific Research (Belgium) for personnel and research grants.

\section{REFERENCES}

1. Ash, C., Farrow, J. A. E., Wallbanks, S. \& Collins, M. D. (1991). Phylogenetic heterogeneity of the genus Bacillus revealed by comparative analysis of small-subunit-ribosomal RNA sequences. Lett Appl Microbiol 13, 202-206.

2. Ash, C., Priest, F. G. \& Collins, M. D. (1993). Molecular identification of rRNA group 3 bacilli (Ash, Farrow, Wallbanks and Collins) using a PCR probe test. Antonie Leeuwenhoek J Microbiol 64, 253-260.

3. Claus, D. \& Berkeley, R. C. W. (1986). Genus Bacillus Cohn 1872. In Bergey's Manual of Systematic Bacteriology, vol. 2, 
pp. 1105-1139. Edited by P. H. A. Sneath, N. S. Mair, M. E. Sharpe \& J. G. Holt. Baltimore: Williams \& Wilkins.

4. Claus, D. \& Fahmy, F. (1986). Genus Sporosarcina Kluyver and van Niel 1936. In Bergey's Manual of Systematic Bacteriology, vol. 2, pp. 1202-1206. Edited by P. H. A. Sneath, N. S. Mair, M. E. Sharpe \& J. G. Holt. Baltimore: Williams \& Wilkins.

5. Costas, M. (1992). Classification, identification, and typing of bacteria by the analysis of their one-dimensional polyacrylamide gel electrophoretic protein patterns. In Advances in Electrophoresis, vol. 5, pp. 351-408. Edited by A. Chambrach, M. J. Dunn \& B. J. Radola. Weinheim: VCH Verlagsgesellschaft.

6. DSMZ catalogue of strains (1993). Deutsche Sammlung von Mikroorganismen und Zellkulturen $\mathrm{GmbH}$, Braunschweig, Germany.

7. Fahmy, F., Flossdorf, J. \& Claus, D. (1985). The DNA base composition of the type strains of the genus Bacillus. Syst Appl Microbiol 6, 60-65.

8. Farrow, J. A. E., Ash, C., Wallbanks, S. \& Collins, M. D. (1992). Phylogenetic analysis of the genera Planococcus, Marinococcus and Sporosarcina and their relationships to members of the genus Bacillus. FEMS Microbiol Lett 93, 167-172.

9. Gordon, R. E., Haynes, W. C. \& Pang, C. H.-N. (1973). The genus Bacillus. Agriculture Handbook no. 427, p. 283. Washington, DC: US Department of Agriculture.

10. Gower, J. C. (1971). A general coefficient of similarity and some of its properties. Biometrics 27, 857-874.

11. Hao, M. V., Kocur, M. \& Komagata, K. (1984). Marinococcus gen. nov., a new genus for motile cocci with mesodiaminopimelic acid in the cell wall; and Marinococcus albus sp. nov. and Marinococcus halophilus (Novitsky and Kushner) comb. nov. J Gen Appl Microbiol 30, 449-459.

12. Heyndrickx, H., Lebbe, L., Vancanneyt, M., Kersters, K., De Vos, P., Logan, N. A., Forsyth, G., Nazli, S., Ali, N. \& Berkeley, R. C. W. (1997). A polyphasic reassessment of the genus Aneurinibacillus, reclassification of Bacillus thermoaerophilus (Meier-Stauffer et al. 1996) as Aneurinibacillus thermoaerophilus comb. nov., and emended descriptions of $A$. aneurinilyticus corrig., $A$. migulanus, and $A$. thermoaerophilus. Int J Syst Bacteriol 47, 808-817.

13. Heyndrickx, M., Vandemeulebroecke, K., Scheldeman, P., Kersters, K., De Vos, P., Logan, N. A., Aziz, A. M., Ali, N. \& Berkeley, R. C. W. (1996). A polyphasic reassessment of the genus Paenibacillus, reclassification of Bacillus lautus (Nakamura 1984) as Paenibacillus lautus comb. nov. and of Bacillus peoriae (Montefusco et al. 1993) as Paenibacillus peoriae comb. nov. Emended descriptions of $P$. lautus and of $P$. peoriae. Int J Syst Bacteriol 46, 988-1003.

14. Heyndrickx, M., Vauterin, L., Vandamme, P., Kersters, K. \& De Vos, P. (1996). Applicability of combined amplified 16S rDNA restriction analysis (ARDRA) patterns in bacterial phylogeny and taxonomy. $J$ Microbiol Methods 26, 247259.

15. International Committee on Systematic Bacteriology (1993).
Minutes of the Subcommittee on the Taxonomy of the Genus Bacillus. Int J Syst Bacteriol 43, 185.

16. Lawson, P. A., Deutch, C. E. \& Collins, M. D. (1996). Phylogenetic characterization of a novel salt-tolerant Bacillus species: description of Bacillus dipsosauri sp. nov. $J$ Appl Bacteriol 81, 109-112.

17. Logan, N. A. \& Berkeley, R. C. W. (1984). Identification of Bacillus strains using the API system. J Gen Microbiol 130, 1871-1882.

18. Niimura, Y., Koh, E., Yanagida, F., Suzuki, K.-I., Komagata, K. \& Kozaki, M. (1990). Amphibacillus xylanus gen. nov., sp. nov., a facultatively anaerobic sporeforming xylan-digesting bacterium which lacks cytochrome, quinone, and catalase. Int J Syst Bacteriol 40, 297-301.

19. Pitcher, D. G., Saunders, N. A. \& Owen, R. J. (1989). Rapid extraction of bacterial genomic DNA with guanidium thiocyanate. Lett Appl Microbiol 8, 151-156.

20. Pot, B., Vandamme, P. \& Kersters, K. (1994). Analysis of electrophoretic whole organism protein fingerprints. In Chemical Methods in Prokaryotic Systematics, pp. 493-521. Edited by M. Goodfellow \& A. G. O'Donnell. Chichester: Wiley.

21. Proom, H. \& Knight, B. C. J. G. (1950). Bacillus pantothenticus (n.sp.). J Gen Microbiol 4, 539-541.

22. Sasser, M. (1997). MIDI: technical note 102. Newark, DE: Barksdale Prof. Center.

23. Shida, O., Takagi, H., Kadowaki, K. \& Komagata, K. (1996). Proposal for two new genera, Brevibacillus gen. nov. and Aneurinibacillus gen. nov. Int J Syst Bacteriol 46, 939-946.

24. Spring, S., Ludwig, W., Marquez, M. C., Ventosa, A. \& Schleifer, K.-H. (1996). Halobacillus gen. nov., with descriptions of Halobacillus litoralis sp. nov. and Halobacillus trueperi sp. nov., and transfer of Sporosarcina halophila to Halobacillus halophilus comb. nov. Int J Syst Bacteriol 46, 492-496.

25. Vauterin, L., Yang, P., Hoste, B., Vancanneyt, M., Civerolo, E. L., Swings, J. \& Kersters, K. (1991). Differentiation of Xanthomonas campestris pv. citri strains by sodium dodecyl sulfate-polyacrylamide gel electrophoresis of proteins, fatty acid analysis, and DNA-DNA hybridization. Int $J$ Syst Bacteriol 41, 535-542.

26. Vauterin, L. \& Vauterin, P. (1992). Computer aided objective comparison of electrophoretic patterns for grouping and identification of microoganisms. Eur Microbiol 1, 37-41.

27. Watanuki, M. \& Aida, K. (1972). Significance of quinones in the classification of bacteria. J Gen Appl Microbiol 18, $469-472$.

28. Wisotzkey, J. D., Jurtshuk, P., Jr, Fox, G. E., Deinhard, G. \& Poralla, K. (1992). Comparative sequence analyses on the 16S rRNA (rDNA) of Bacillus acidocaldarius, Bacillus acidoterrestris, and Bacillus cycloheptanicus and proposal for creation of a new genus, Alicyclobacillus gen. nov. Int $J$ Syst Bacteriol 42, 263-269. 